\title{
TORSIONAL STRENGTH OF STEEL FIBER REINFORCED CONCRETE
}

\author{
Muhammad I. Rjoub ${ }^{1}$ \\ Civil Engineering Department, Faculty of Engineering Technology, Al-Balqa' Applied \\ University. Amman 11134, P.O. Box 15008, Jordan \\ Mazen A. Musmar ${ }^{2}$ \\ Civil Engineering Department, Faculty of Engineering Technology, Al-Balqa' Applied \\ University Amman 11134, P.O. Box 15008, Jordan \\ Email: $\underline{\text { m_musmar@wanadoo.jo }}$
}

(Received October 4, 2006 Accepted November 29, 2006)

\begin{abstract}
The addition of steel fibers in reinforced concrete improves the toughness and the tensile strength of the obtained steel fiber reinforced concrete (SFRC). The latter property enhances the shear strength and the torque moment capacity of SFRC which mainly depend on the tensile strength.

The current study is targeted towards developing an expression that is based on the thin walled tube (space truss) analogy adopted by American concrete Institute (ACI). In the proposed expression, the effective tensile strength of concrete in pure torsion in addition to parameters that are in accordance with thin walled tube (space truss) analogy are introduced as independent input parameters.

Literature survey is carried out to collect experimental data pertinent to the torsional strength of SFRC beams. Based on regression analysis a new mathematical relationship that predicts the torsional moment for fiber reinforced concrete is derived.
\end{abstract}

\section{1- INTRODUCTION}

The addition of steel fibers to concrete mixes improves the properties of the obtained steel fiber reinforced concrete (SFRC). Aspects of the improved properties comprise tensile strength, shear strength as well as ductility and toughness of the SFRC. Such enhancements render using steel fibers attractive especially in high strength concrete.

Utilizing steel fibers as a technique for improving the properties of concrete has been the issue of several studies steered to acquire better understanding of the behavior of SFRC both in linear and nonlinear stages, and to attain detailed authenticated provisions for the design of such material. 
Few studies have been targeted towards investigating the torsional capacity of SFRC concrete. According to Edington [1], the increase in both the direct tensile and the torsional strengths of unreinforced concrete because of the fibers is substantial compared to only a marginal increase in flexural strength.

Upon testing eight SFRC beams, of various fiber content proportions with dimensions 6in width, 12in height, 70in length, Craig [2] concluded that the addition of fibers shows a tremendously increased ductility over the plain concrete.

Romouldi [3] inferred that fibers act as crack arrestors by producing pinching forces that tend to close a crack. Sakai [4] concluded that the critical fiber transfer length, the fiber matrix interfacial bond, and the orientation factor for random fibers are the basic considerations in the transfer of stress from matrix to fiber.

Rao [5] tested 20 SFRC plain concrete beams of size $100 \times 200 \times 1000$ $\mathrm{mm}$ under pure torsion. The volume fraction of fibers varied from $0 \%$ to $1.2 \%$, the grades of concrete were $20,30,40,50$. He concluded that torsional failure of concrete members is initiated by the tensile stress that comes up due to a state of in plane pure shear developed by torsion. According to his study, inclusion of steel fibers may principally increase the tensile strength of the matrix to a moderate level but the toughness will be enhanced to a greater extent.

Mansur [6] conducted experiments on 30 beams, in which torsion to moment ratio varied from 0 , pure bending to $\infty$, pure torsion. Beams lengths were $1 \mathrm{~m}, 2 \mathrm{~m}$, the sections depths were $100,150,200 \mathrm{~mm}$ while a constant width of $100 \mathrm{~mm}$ was maintained.

Also Mansur [7] carried out experiments on 15 beams, each 1m. long with a rectangular cross section of $100 \mathrm{~mm}$ by $155 \mathrm{~mm}$. The beams were divided into four groups according to the fiber volume fraction of $0,0.75,1.25$ and $1.75 \%$. Mansur [7, 8] concluded that increase in volume fraction of fibers adds to the torsional ductility, and the toughness of tested beams.

\section{2- RESEARCH SIGNIFICANCE}

Addition of steel fibers in concrete improves its mechanical behavior. The material ductility is enhanced significantly. The crack growth is considerably decreased. The material becomes a better energy absorbing. Such improvements support the use of SFRC concrete in many structural applications such as airports, highway paving layers, industrial floorings, and bridge decks. Its enhanced properties support its use in structures in earthquake prone regions, and for blast resistant structures. The authors strongly feel that this work will help to shed more light on the torsional capacity of steel fiber concrete. 


\section{3- DATA ANALYSIS}

Experimental data obtained from testing SFRC plain concrete beams under pure torsion are listed in Table 1. Gathered data contain cubic compressive strength values for SFRC that range from $22 \mathrm{MPa}$ to $61 \mathrm{MPa}$. These values practically cover all structural concrete grades used in construction works.

According to Rao [5], as the state of stress is pure shear accompanied by the same intensity of compressive and tensile stresses in orthogonal directions, the apparent tensile strength drops a little less than the actual tensile strength of concrete. So the effective tensile strength of concrete in pure torsion is taken as

$$
1 / f_{t}=1 / f_{c}+1 / f_{s p t}
$$

Where

$f_{t}$ : the effective tensile strength of concrete in pure torsion

$f_{\text {spt }}$ : Split cylinder tensile strength

$f_{c}$ : Concrete cubic strength.

Moreover, according to ACI, a beam subjected to torsion is idealized as a thin walled tube with the core concrete cross section neglected, space truss analogy, the torsional moment is a function of $\sqrt{f_{c}^{\prime}},\left(\frac{A_{c p}^{2}}{p_{c p}}\right)$

where $f_{c}^{\prime}=$ specified compressive strength of concrete.

$A_{c p}=$ area enclosed by outside perimeter of concrete cross section.

$p_{c p}=$ outside perimeter of the concrete cross section.

The above parameters are exploited in introducing the general expression

$$
T=\alpha \cdot\left(\frac{A_{c p}^{2}}{p_{c p}}\right) \cdot f_{t}
$$

where $f_{t}=$ effective tensile strength of concrete in pure torsion, Eq. (1), MPa.

$T=$ torsional moment strength, $\mathrm{KNm}$.

Regression analysis is conducted on the tentative equation. Ultimately the following equation is derived

$$
T=0.833 .\left(\frac{A_{c p}^{2}}{p_{c p}}\right) \cdot f_{t}
$$

The P-value for the coefficient $(\alpha)$ is less than 0.001 , indicating that the predictor has a significant effect on the response variable. Also the adjusted coefficient of determination, $\mathrm{R}^{2}$ is 0.9 , implying that the predicted values are acceptably close to the observed data. 
Up to the knowledge of the authors, and as was asserted through the literature survey, till now there is no authenticated mathematical expression concerning the torsional strength of fiber reinforced concrete. Thus, Fig. 1 illustrates a comparison between the calculated torsion according to the derived equation with the calculated value of torsion for plain concreted according to the American concrete Institute (ACI) equation for plain concrete:

$$
T=\left(\frac{1}{3}\right) \operatorname{sqrt}\left(f^{\prime} c\right) \times \frac{\left(A_{c p}\right)^{2}}{p_{c p}} \times 10^{-6}
$$

where $f_{c}^{\prime}=$ specified compressive strength of concrete (MPa).

$T$ = torsional moment strength, KNm.

As illustrated in Fig. 1, using the effective tensile strength in the case of steel fiber reinforced concrete enhances the calculated torsional strength values. Figure 2 illustrates the relationship of concrete compressive strength, effective tensile in pure torsion versus $\mathrm{T}_{\exp } / / \mathrm{T}_{\text {cal }}$.

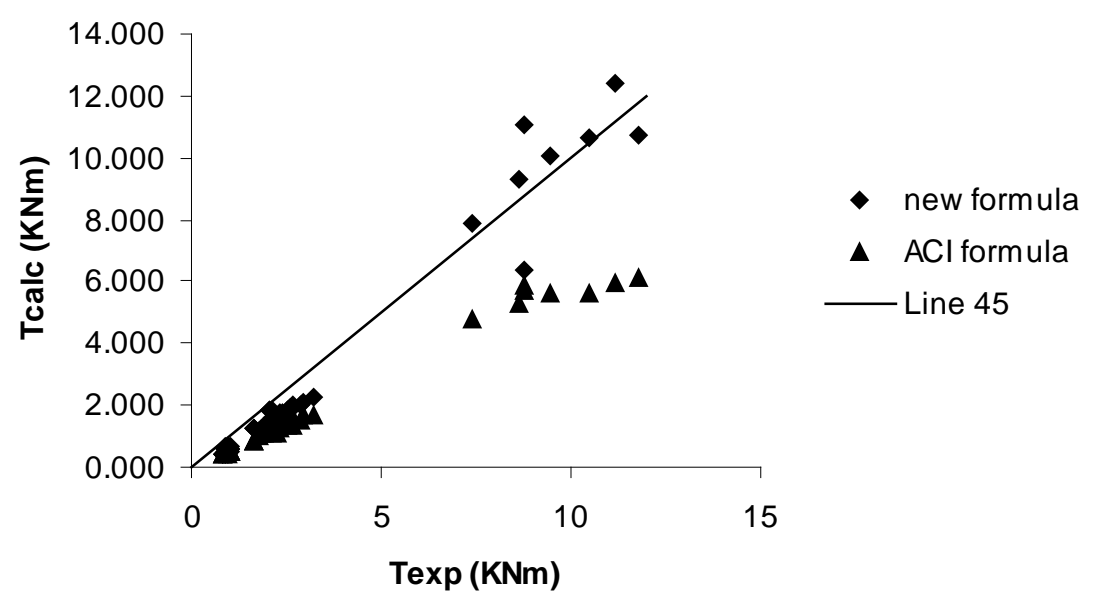

Figure 1 Experimental values of torsion $\left(\mathrm{T}_{\text {exp }}\right)$ versus calculated torsion $\left(\mathrm{T}_{\text {cal }}\right)$ according, first according to proposed equation, then according to ACI equation.

\section{4- CONCLUSIONS}

Addition of steel fiber into the concrete mix increases the tensile strength of concrete; nevertheless the compressive strength is slightly affected. Hence, based on experimental results, a general expression for SFRC beams subjected to torsion is suggested. This expression is deducted from the ACI equation for determination of torsional capacity in case of plain concrete beams. The tensile strength parameter that actually reflects the enhancement in torsional strength 
of rectangular steel fiber reinforced concrete is used instead of the concrete compressive cylindrical strength presented in the original ACI equation. The final expression is concluded using regression analysis on experimental values. The calculated values utilizing the derived equation are in good agreement with experimental values.

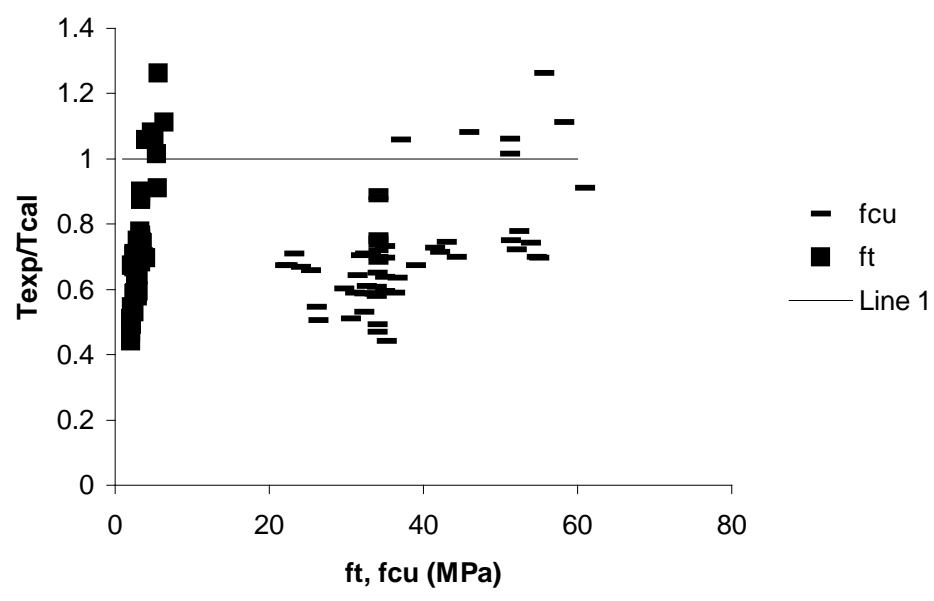

Figure 2 experimental fcu, $\mathrm{f}_{\mathrm{t}}$ values versus $\mathrm{T}_{\text {exp }} / \mathrm{T}_{\mathrm{cal}}$

\section{REFERENCES}

1. Edington, J, "Steel fiber reinforced concrete", Research Report submitted to the Department of Environment, Jan. 1974.

2. R. John Craig, James A. Parr, Eddy Germain, Victor Mosquera, and stavros Kamilares, American concrete Institute ACI Journal, Nov-dec. 1986.

3. J. p. Romuildi, and Mandel. J. A. "Tensile Strength of concrete affected by uniformly distributed and closely spaced short lengths of wire reinforcement. ACI Journal. Proc. Vol. 61, No.6. June 1964. pp657-671.

4. M. Sakai, and N. Nakamura, "Analysis of flexural behavior of steel fiber reinforced concrete", in RILEM Symp. on development in fiber reinforced cement and concrete. University of Sheffield Press. July 1986.

5. T.D. Gunneswara Rao, D. Rama Seshu, Torsion of steel fiber reinforced concrete members, Cement and Concrete Research 33, May, 2003. 
6. M.A.Mansur, Bending torsion interaction for concrete beams reinforced with steel fibers, Magazine of Concrete Research, Vol.34, No 121, Dec 1982.

7. M. A. Mansur and P. Paramasivam, Steel Fiber Reinforced Concrete in Pure Torsion, The International Journal of Cement Composites and Lightweight Concrete, Vol. 4, No.1, Feb 1982.

8. M. A. Mansur and T. Y. Lim, Torsional Behavior of Reinforced Fiber Concrete Beams, The International Journal of Cement Composites and Lightweight Concrete, Vol. 7, No.4, Nov 1985.

\section{APPENDIX}

Table (1) Calculated and experimental torsional moments.

\begin{tabular}{|c|c|c|c|c|c|c|c|c|c|}
\hline & $\mathrm{mm}$ & $\mathrm{mm}$ & Mpa & Mpa & Mpa & $\mathrm{KNm}$ & $\mathrm{KNm}$ & \\
\hline & & $b$ & $d$ & $\mathrm{ft}$ & Fcu & fsp & Texp & Tcal & Tcal/Texp \\
\hline \multirow{20}{*}{$\begin{array}{l}\tilde{\sigma} \\
\stackrel{\sigma}{\sigma} \\
\widetilde{\alpha}\end{array}$} & 1 & 100 & 200 & 2.12 & 22.00 & 2.35 & 1.753 & 1.179 & 0.672 \\
\hline & 2 & 100 & 200 & 2.28 & 22.41 & 2.54 & 1.881 & 1.267 & 0.673 \\
\hline & 3 & 100 & 200 & 2.46 & 23.26 & 2.75 & 1.924 & 1.365 & 0.710 \\
\hline & 4 & 100 & 200 & 2.53 & 24.15 & 2.82 & 2.095 & 1.402 & 0.669 \\
\hline & 5 & 100 & 200 & 2.68 & 25.41 & 3.00 & 2.266 & 1.490 & 0.657 \\
\hline & 6 & 100 & 200 & 2.49 & 31.86 & 2.70 & 1.967 & 1.382 & 0.703 \\
\hline & 7 & 100 & 200 & 2.79 & 32.41 & 3.05 & 2.180 & 1.548 & 0.710 \\
\hline & 8 & 100 & 200 & 2.99 & 33.16 & 3.29 & 2.351 & 1.662 & 0.707 \\
\hline & 9 & 100 & 200 & 3.35 & 34.21 & 3.71 & 2.522 & 1.858 & 0.737 \\
\hline & 10 & 100 & 200 & 3.50 & 35.01 & 3.89 & 2.651 & 1.944 & 0.733 \\
\hline & 11 & 100 & 200 & 2.74 & 38.99 & 2.95 & 2.266 & 1.523 & 0.672 \\
\hline & 12 & 100 & 200 & 3.13 & 41.54 & 3.39 & 2.394 & 1.740 & 0.727 \\
\hline & 13 & 100 & 200 & 3.25 & 42.20 & 3.52 & 2.522 & 1.804 & 0.715 \\
\hline & 14 & 100 & 200 & 3.50 & 43.02 & 3.81 & 2.608 & 1.943 & 0.745 \\
\hline & 15 & 100 & 200 & 3.66 & 44.31 & 3.99 & 2.907 & 2.032 & 0.699 \\
\hline & 16 & 100 & 200 & 2.89 & 51.31 & 3.06 & 2.138 & 1.603 & 0.750 \\
\hline & 17 & 100 & 200 & 3.24 & 52.38 & 3.45 & 2.309 & 1.797 & 0.778 \\
\hline & 18 & 100 & 200 & 3.55 & 53.91 & 3.80 & 2.651 & 1.971 & 0.743 \\
\hline & 19 & 100 & 200 & 3.71 & 54.75 & 3.98 & 2.950 & 2.060 & 0.698 \\
\hline & 20 & 100 & 200 & 4.01 & 55.05 & 4.33 & 3.206 & 2.229 & 0.695 \\
\hline \multirow{6}{*}{$\begin{array}{l}\bar{N} \\
\frac{\sigma}{\sigma} \\
\frac{\sigma}{U}\end{array}$} & 21 & 152 & 305 & 3.24 & 52.12 & 3.45 & 8.779 & 6.337 & 0.722 \\
\hline & 22 & 152 & 305 & 5.13 & 51.23 & 5.70 & 9.457 & 10.045 & 1.062 \\
\hline & 23 & 152 & 305 & 4.75 & 45.93 & 5.30 & 8.609 & 9.305 & 1.081 \\
\hline & 24 & 152 & 305 & 4.01 & 37.10 & 4.50 & 7.423 & 7.859 & 1.059 \\
\hline & 25 & 152 & 305 & 5.66 & 55.65 & 6.30 & 8.779 & 11.082 & 1.262 \\
\hline & 26 & 152 & 305 & 5.46 & 60.95 & 6.00 & 11.750 & 10.697 & 0.910 \\
\hline
\end{tabular}




\begin{tabular}{|c|c|c|c|c|c|c|c|c|c|}
\hline & 27 & 152 & 305 & 5.42 & 51.23 & 6.06 & 10.451 & 10.612 & 1.015 \\
\hline & 28 & 152 & 305 & 6.33 & 58.30 & 7.10 & 11.140 & 12.389 & 1.112 \\
\hline \multirow{9}{*}{$\begin{array}{l}\bar{\theta} \\
\overline{\bar{\omega}} \\
0 \\
\frac{\pi}{\sigma} \\
\Sigma\end{array}$} & 29 & 100 & 100 & 3.32 & 34.20 & 3.68 & 0.961 & 0.691 & 0.719 \\
\hline & 30 & 100 & 100 & 3.32 & 34.20 & 3.68 & 0.990 & 0.691 & 0.698 \\
\hline & 31 & 100 & 100 & 3.32 & 34.20 & 3.68 & 1.010 & 0.691 & 0.684 \\
\hline & 32 & 100 & 150 & 3.32 & 34.20 & 3.68 & 1.668 & 1.244 & 0.746 \\
\hline & 33 & 100 & 150 & 3.32 & 34.20 & 3.68 & 1.648 & 1.244 & 0.755 \\
\hline & 34 & 100 & 150 & 3.32 & 34.20 & 3.68 & 1.624 & 1.244 & 0.766 \\
\hline & 35 & 100 & 200 & 3.32 & 34.20 & 3.68 & 2.109 & 1.843 & 0.874 \\
\hline & 36 & 100 & 200 & 3.32 & 34.20 & 3.68 & 2.050 & 1.843 & 0.899 \\
\hline & 37 & 100 & 200 & 3.32 & 34.20 & 3.68 & 2.089 & 1.843 & 0.882 \\
\hline \multirow{22}{*}{ 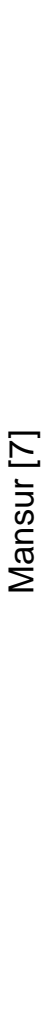 } & 38 & 100 & 100 & 2.04 & 26.40 & 2.22 & 0.844 & 0.426 & 0.504 \\
\hline & 39 & 100 & 100 & 2.13 & 26.20 & 2.32 & 0.814 & 0.444 & 0.546 \\
\hline & 40 & 100 & 100 & 2.02 & 30.60 & 2.16 & 0.824 & 0.420 & 0.509 \\
\hline & 41 & 100 & 100 & 2.56 & 36.30 & 2.76 & 0.905 & 0.533 & 0.589 \\
\hline & 42 & 100 & 100 & 2.54 & 32.30 & 2.76 & 0.902 & 0.529 & 0.586 \\
\hline & 43 & 100 & 100 & 2.73 & 36.60 & 2.95 & 0.893 & 0.568 & 0.636 \\
\hline & 44 & 100 & 100 & 2.82 & 35.00 & 3.07 & 0.923 & 0.588 & 0.637 \\
\hline & 45 & 100 & 100 & 2.87 & 34.10 & 3.14 & 0.922 & 0.598 & 0.649 \\
\hline & 46 & 100 & 100 & 3.06 & 35.00 & 3.35 & 0.915 & 0.637 & 0.696 \\
\hline & 47 & 100 & 100 & 2.08 & 34.10 & 2.22 & 0.923 & 0.433 & 0.469 \\
\hline & 48 & 100 & 100 & 2.18 & 34.10 & 2.32 & 0.922 & 0.453 & 0.491 \\
\hline & 49 & 100 & 100 & 2.03 & 35.20 & 2.16 & 0.963 & 0.423 & 0.440 \\
\hline & 50 & 100 & 100 & 2.55 & 33.60 & 2.76 & 0.903 & 0.530 & 0.587 \\
\hline & 51 & 100 & 100 & 2.54 & 32.30 & 2.76 & 0.996 & 0.529 & 0.531 \\
\hline & 52 & 100 & 100 & 2.71 & 33.90 & 2.95 & 0.932 & 0.564 & 0.606 \\
\hline & 53 & 100 & 100 & 2.81 & 32.70 & 3.07 & 0.959 & 0.584 & 0.609 \\
\hline & 54 & 100 & 100 & 2.84 & 29.70 & 3.14 & 0.981 & 0.591 & 0.602 \\
\hline & 55 & 100 & 100 & 3.03 & 31.50 & 3.35 & 0.981 & 0.631 & 0.643 \\
\hline & 56 & 100 & 100 & 2.80 & 31.10 & 3.07 & 0.986 & 0.582 & 0.590 \\
\hline & 57 & 100 & 100 & 2.97 & 33.70 & 3.25 & 1.055 & 0.618 & 0.586 \\
\hline & 58 & 100 & 100 & 2.91 & 33.90 & 3.18 & 1.045 & 0.605 & 0.579 \\
\hline & 59 & 100 & 100 & 3.00 & 35.00 & 3.28 & 1.050 & 0.624 & 0.594 \\
\hline
\end{tabular}




\section{مقاومة اللي للخرسانة المضاف اليها ألياف فو لاذية}

إن إضافة الألياف الفو لاذية إلى الخرسانة يؤدي الى تحسين متانتها (toughness) وكذلك مقاومتها للشد. هذا وير افق الزيادة في مقاومة الثد زيادة في مقاومة القص وكذلك زيادة في مقاومة اللي.

وتهدف هذه الدر اسة إلى تقديم معادلة لمقاومة اللي لدى المقاطع الخر اسانية المتضمنة ألياف الفو لاذية. ومن أجل تحقيق هذا الغرض تم تطوير معادلة اللي الواردة في الكود الأمريكي و المبنية على مبدأ الجدران النحيفة Thin walled tube analogy) حيث تم الاستعاضة عن مقاومة الخرسانة للضغط الواردة في الكودة بمقاومة الخرسانة للثد اذ أن الدر اسات أثثتت عدم تأثر مقاومة الخرسانة للضغط عند إضافة الألياف الفو لاذية إليها بعكس مقاومتها للثد التي تتحسن بشكل واضح. و عليه تم جمع البيانات للنتائج المخبرية لمقاطع خرسانية معرضة للي وتم إجر اء تحليل إحصائي ارتدادي، وتم استنباط معادلة رياضية لحساب مقاومة اللي في حال المقاطع الخر اسانية المتضمنة ألياف الفو لاذ. الباحث الأول: الدكتور محمد مذيب الرجوب: كلية الهندسة التكنولوجية /قسم الهندسة المدنية/جامعة البلقاء التطبيقية/عمان/1134 ص.ب. 15008 /الأردن الباحث الثاني: الدكتورمازن علي مسمار : كلية الهندسة التكنولوجية/قسم الهندسة المدنية/جامعة البلقاء التطبيقية/عمان/ 1134 ص.ب. 15008 /الأردن 